\title{
Алгоритм ведення пацієнта 3 інгібіторною формою гемофілії
}

\author{
К.В. Вільчевська \\ Національна дитяча спеціалізована лікарня «Охматдит», Київ, Україна \\ ДУ «Інститут невідкладної та відновної хірургії імені В.К. Гусака НАМН України», Київ, Україна
}

Незважаючи на суттєві досягнення в галузі гематології, і досі залишається проблемним питання розвитку інгібіторної форми гемофілії (ІФГ), яка характеризується виробленням інгібіторних антитіл, що становить імунну реакцію на екзогенне введення факторів згортання крові і $\epsilon$ основною клінічною проблемою в лікуванні пацієнтів із гемофілією. Наявність інгібіторів ускладнює тяжкість клінічного перебігу гемофілії, кровотечі набувають неконтрольованого характеру, а замісна терапія факторами згортання крові $\epsilon$ малоефективною [1]. Тому тактика ведення пацієнтів із ІФГ кардинально відрізняється від стандартного підходу до лікування гемофілії.

Принципи лікування пацієнтів із ІФГ:

- протягом усього життя слід знати та пам'ятати про частоту і фактори ризику появи інгібіторів;

- раннє розпізнання і точна діагностика інгібітора;

- оптимальна організація допомоги пацієнту та постійна комунікація між усіма зацікавленими сторонами;

- гемостатична терапія за допомогою шунтуючих препаратів у пацієнтів із інгібіторами;

- ерадикація інгібітора за допомогою методу індукції імунної толерантності (IIT);

- надання доступу до хірургічних та інших інвазивних втручань та оптимальна підготовка до них;

- забезпечення допомоги пацієнту з боку спеціально навченої медичної сестри;

- забезпечення індивідуально підібраної допомоги з боку фізіотерапевта;

- надання доступу до психосоціальної підтримки;

- залучення в наукові дослідження та інновації [2].

Лікування у разі кровотеч, що розвиваються у хворих із ІФГ, може стати серйозною проблемою як для лікаря, так і для самого пацієнта. Сучасні стратегії менеджменту інгібіторів полягають у триетапному підході:

- ерадикація інгібітора: якнайшвидше використання IIT після діагностики інгібітора;

- профілактика кровотеч: запобігання епізодам кровотеч упродовж IIT, або коли IIT неефективна/недоступна пацієнту;

- лікування препаратами із шунтуючим механізмом дії: застосування препаратів із шунтуючим механізмом дії з метою лікування у разі гострих епізодів кровотеч або при хірургічних втручаннях (рис. 1) [3, 4].

Рисунок 1 Стратегії менеджменту інгібітора

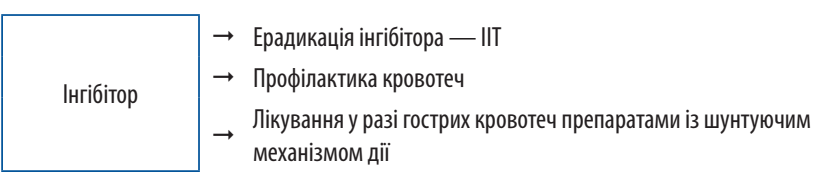

Наявність інгібітора зазвичай діагностується, коли хворий або члени його сім'ї помічають, що замісна терапія стає менш ефективною, ніж зазвичай. Так, ключовим симптомом, який вказує на розвиток інгібітора, $\epsilon$ наявність безконтрольних кровотеч та відсутність відповіді на введення звичайної дози концентратів факторів згортання. Алгоритм менеджменту пацієнтів із ІФГ полягає в тому, що після підозри на розвиток інгібітора необхідним $є$ проведення специфічного тесту Бетезда чи його модифікації Неймегена, який вимірює кількість інгібіторів, виявлених у плазмі крові.
Серед осіб з ІФГ необхідно виокремлювати залежно від титру інгібітора пацієнтів із низьким титром/низькореагуючим (0,6-<5 БО/мл) та високим титром/високореагуючим інгібітором ( $\geq 5$ БО/мл). Титр інгібітора визначають за ступенем відповіді на стимуляцію імунної системи пацієнта повторними введеннями факторів згортання крові. У хворих із низьким/ низькореагуючим титром інгібітора замісна терапія FVIII/FIX часто дає хорошу відповідь, дозволяючи успішно справлятися з незначними кровотечами, хоча для подолання дії інгібітора можлива потреба у введенні більшої кількості препарату. Так, відповідно до сучасних рекомендацій Організації лікарів Центру гемофілії Великобританії (The United Kingdom Haemophilia Centre Doctors' Organisation - UKHCDO) 2017 р., IIT $\epsilon$ головним терапевтичним методом елімінації інгібітора, який рекомендовано розпочинати одразу після підтвердження наявності інгібіторів, незалежно від титру [5]. Однак у пацієнтів із високим/високореагуючим титром інгібітора стандартна терапія $\epsilon$ неефективною, оскільки навіть велика кількість фактора нейтралізується інгібітором. У рідкісних випадках, коли при високому титрі антитіл стан хворого стає загрозливим, доцільним $\epsilon$ видалення інгібітора за допомогою плазмаферезу. Однак цей захід має тимчасовий ефект, оскільки введення фактора стимулюватиме вироблення нових інгібіторів протягом декількох днів. Відповідно, для більшості епізодів кровотечі хворі на гемофілію з високим/високореагуючим титром інгібітора повинні покладатися на альтернативні варіанти лікування. За неможливості проведення чи неефективності ІІТ профілактику кровотеч можна проводити препаратом нефакторної терапії (еміцизумаб) або препаратами із шунтуючим механізмом дії, такими як антиінгібіторний коагуляційний комплекс або рекомбінантний активований FVII, які мають тривалу історію застосування у пацієнтів з ІФГ, зокрема як супровід IIT [6, 7] (рис. 2).

Рисунок 2 Алгоритм менеджменту пацієнтів із ІФГ

Наявність безконтрольних кровотеч та відсутність відповіді на введення звичайної дози концентратів FVIII/FIX?

\begin{tabular}{|c|c|}
\hline \multicolumn{2}{|c|}{ Чи наявний інгібітор до FVIII/FIX? } \\
\hline Tак $\downarrow$ & $\mathrm{Hi} \downarrow$ \\
\hline $\begin{array}{c}\text { ІІТ/терапія препаратами із шунтуючим } \\
\text { механізмом дії }\end{array}$ & $\begin{array}{c}\text { Динамічне спостереження/корекція } \\
\text { режиму і доз введення концентратів FVIII/ } \\
\text { FIX, терапія супутньої патології }\end{array}$ \\
\hline \multicolumn{2}{|l|}{$\downarrow$} \\
\hline \multicolumn{2}{|c|}{ Наявна відповідь на терапію через 6-12 міс? } \\
\hline Так $\downarrow$ & $\mathrm{Hi} \downarrow$ \\
\hline $\begin{array}{c}\text { Продовжити IIT/терапію препаратами } \\
\text { із шунтуючим механізмом дії }\end{array}$ & $\begin{array}{c}\text { Зміна препаратів із шунтуючим } \\
\text { механізмом дії/високі дози концентратів } \\
\text { FVIII/FIX за фактом кровотечі }\end{array}$ \\
\hline \multicolumn{2}{|l|}{$\downarrow$} \\
\hline \multicolumn{2}{|c|}{ Досягнуто ерадикації інгібітора? } \\
\hline Так $\downarrow$ & $\mathrm{Hi} \downarrow$ \\
\hline $\begin{array}{c}\text { Профілактична терапія концентратами } \\
\text { FVIII/FIX }\end{array}$ & $\begin{array}{c}\text { Терапія препаратами із шунтуючим } \\
\text { механізмом дії чи нефакторна терапія }\end{array}$ \\
\hline
\end{tabular}

За підтримки ТОВ «Такеда Україна» VV-MEDMAT-37249 


\section{Список використаної літератури/References:}

1. Scalone L., Mantovani L.G., Mannucci P.M. et al. (2006) Quality of life is associated to the orthopaedic status in haemophilic patients with inhibitors. Haemophilia, 12(2): 154-162. doi: $10.1111 / j .1365-2516.2006 .01204 . x$

2. Giangrande P.L.F., Hermans C., $0^{\prime}$ Mahony B. et al. (2018) European principles of inhibitor management in patients with haemophilia. Orphanet. J. Rare Dis., 13: 66. https://doi. org/10.1186/s13023-018-0800-z

3. Collins P.W., Chalmers E., Hart D.P. et al. (2013) Diagnosis and treatment of factor VIII and IX inhibitors in congenital haemophilia: (4 $4^{\text {th }}$ ed.). UK Haemophilia Centre Doctors Organization. Br. J. Haematol., 160(2): 153-170. doi: 10.1111/bjh. 12091

4. Hay C.R.M., Brown S., Collins P.W. et al. (2006) The diagnosis and management of factor VIII and IX inhibitors: a guideline from the United Kingdom Haemophilia Cen-

\section{Відомості про автора:}

Вільчевська Катерина Вікторівна — кандидат медичних наук, завідувач Центру патологї гемостазу Національної дитячої спеціалізованої лікарні «Охматдит», завідувач центру патологї гемостазу ДУ «Інститут невідкладної та відновної хірургії імені В.К. Гусака НАМН України», Київ, Україна. Адреса для кореспонденції: Вільчевська Катерина Вікторівна 01135, м. Київ, вул. Шолуденка, 10 E-mail: dr.vilchevska@gmail.com tre Doctors Organisation. Br. J. Haematol., 133(6): 591-605. doi: 10.1111/j.13652141.2006.06087.x

5. Gomez K., Laffan M., Keeney S. et al. (2019) Recommendations for the clinical interpretation of genetic variants and presentation of results to patients with inherited bleeding disorders. A UK Haemophilia Centre Doctors'Organisation Good Practice Paper. Haemophilia, 25: 116-126.

6. Srivastava A., Santagostino E., Dougall A. et al. (2020) WFH Guidelines for the Management of Hemophilia, $3^{\text {rd }}$ ed. Haemophilia, 26(Suppl. 6): 1-158. doi: 10.1111/hae.14046

7. Collins P., Chalmers E., Alamelu J. et al. (2017) First-line immune tolerance induction for children with severe haemophilia A: A protocol from the UK Haemophilia Centre Doctors' Organisation Inhibitor and Paediatric Working Parties. Haemophilia, 23(5): 654-659. doi: 10.1111/hae.13264

\section{Information about the author:}

Vilchevska Kateryna V. — Candidate of Medical Sciences, Head of the Center of hemostasis pathology of the National Children Special Hospital «Ohmatdet», Head of the Center of hemostasis pathology of the V.K. Gusak Institute of Urgent and Recovery Surgery of NAMS of Ukraine, Kyiv, Ukraine.

Address for correspondence:

Kateryna Vilchevska

01135, Kyiv, Sholudenko str., 10

E-mail: dr.vilchevska@gmail.com

Надійшла до редакції/Received: 18.01.2021

Прийнято до друку/Accepted: 28.01.2021

ТЕСТОВІ ЗАПИТАННЯ

(один або декілька правильних варіантів відповідей на кожне запитання)

1. Визначте основну клінічну проблему в лікуванні пацієнтів із гемофілією:

$\square$ розвиток інгібіторної форми гемофілії

$\square$ розвиток остеопорозу

$\square$ розвиток алергічних реакцій

$\square$ усе вищезазначене

2. Визначте принципи лікування пацієнтів із інгібіторами:

$\square$ раннє розпізнання і точна діагностика інгібітора

$\square$ гемостатична терапія за допомогою шунтуючих препаратів

$\square$ ерадикація інгібітора за допомогою IIT

$\square$ застосування глюкокортикостероїдів при кровотечах

3. Сучасні стратегії менеджменту ІФГ полягають у:

$\square$ ерадикації інгібітора

$\square$ профілактиці кровотеч

$\square$ усуненні кровотеч препаратами із шунтуючим механізмом дії

$\square$ усі відповіді правильні

4. Ерадикація інгібітора полягає у:

$\square$ якнайшвидшому застосуваннні IIT

$\square$ інфузійній терапії кристалоїдними розчинами

$\square$ застосуванні глюкокортикостероїдів

$\square$ усі відповіді правильні

5. Визначте перший симптом, який вказує на розвиток інгібітора до факторів згортання крові: $\square$ наявність безконтрольних кровотеч, які не купіруються стандартними дозами концентратів факторів згортання

$\square$ розвиток кропив'янки

$\square$ артропатія

$\square$ усі відповіді правильні

6. Головним терапевтичним методом елімінації інгібітора $є$ :
$\square$ велике ортопедичне оперативне втручання
$\square$ індукція імунної толерантності
$\square$ терапія глюкокортикостероїдами
$\square$ нефакторна терапія

7. За неможливості проведення або неефективності IIT профілактику кровотеч рекомендовано проводити:

$\square$ препаратами із шунтуючим механізмом дії чи препаратом нефакторної терапії

$\square$ глюкокортикостероїдами

$\square$ додати до терапії аскорбінову кислоту

$\square$ усі відповіді правильні

8. Визначте препарати із шунтуючим механізмом дії:

$\square$ антиінгібіторний коагуляційний комплекс

$\square$ концентрат FVIII

$\square$ рекомбінантний активований FVII

$\square$ концентрат FIX

$\square$ усі відповіді правильні

\section{Для отримання сертифіката дайте відповідь на тестові запитання в режимі on-line на сайті журналу www.umj.com.ua або надішліть ксерокопію сторінок з відповідями разом з контактною інформацією за адресою: \\ 01001, Київ-1, a/c «В»-82, ТОВ «МОРІOН»}

ПІБ

Поштова адреса: індекс

область

район

місто

вулиця

будинок

квартира

Телефон

E-mail 